\title{
PENGARUH KOMPENSASI TERHADAP KINERJA KARYAWAN PADA PT TRIMULYA INTERBUANA DI TANGERANG SELATAN
}

\author{
${ }^{1}$ Eko Novianto Nugroho Hadi, ${ }^{*}$ Yayan Sudaryana \\ Universitas Pamulang, Tangerang Selatan, Banten, Indonesia \\ *dosen00497@unpam.ac.id
}

\begin{abstract}
Abstrak
Penelitian ini bertujuan untuk mengetahui pengaruh kompensasi terhadap kinerja karyawan pada PT. Trimulya Interbuana di Tangerang Selatan. Metode yang digunakan adalah explanatory research dengan sampel sebanyak 52 responden. Teknik analisis menggunakan analisis statistik dengan pengujian regresi, korelasi, determinasi dan uji hipotesis. Hasil penelitian ini variabel kompensasi diperoleh nilai rata-rata skor sebesar 3,348 dengan kriteria baik. Variabel kinerja karyawan diperoleh nilai rata-rata skor sebesar 3,813 dengan kriteria baik. Kompensasi berpengaruh positif dan signifikan terhadap kinerja karyawan dengan nilai persamaan regresi $\mathrm{Y}=8,411+0,888 \mathrm{X}$, dan nilai koefisien korelasi 0,734 atau memiliki tingkat hubungan yang kuat dengan nilai determinasi 53,8\%. Uji hipotesis diperoleh signifikansi 0,000 <0,05.
\end{abstract}

Kata Kunci: Kompensasi, Kinerja Karyawan

\section{Abstract}

This study aims to determine the effect of compensation on employee performance at PT. Trimulya Interbuana in South Tangerang. The method used is explanatory research with a sample of 52 respondents. The analysis technique uses statistical analysis with regression, correlation, determination and hypothesis testing. The results of this research variable compensation obtained an average score of 3,348 with good criteria. Employee performance variable obtained an average score of 3.813 with good criteria. Compensation has a positive and significant effect on employee performance with the value of the regression equation $Y=8.411+0.888 X$, and the correlation coefficient value of 0.734 or has a strong relationship with a determination value of $53.8 \%$. Hypothesis testing obtained a significance of $0.000<0.05$.

Keywords: Compensation, Employee Performance

\section{PENDAHULUAN}

Dalam mengelola dan mengatur perusahaan dibutuhkan manajemen dalam perusahaan salah satunya adalah Manajemen Sumber Daya Manusia, yang memiliki kedudukan yang sangat penting dan strategis di dalam organisasi untuk dapat berfungsi secara produktif untuk tercapainya tujuan perusahaan. dalam upaya pencapaian tujuan perusahaan tersebut Sumber Daya Manusia menjadi salah satu sebagai pengerak organisasi, maka upaya-upaya organisasi dalam mendorong karyawan untuk bekerja harus terus dilakukan, setiap organisasi maupun perusahaan akan selalu berusaha untuk meningkatkan kinerja karyawan, dengan harapan apa yang menjadi tujuan perusahaan akan tercapai. Dengan adanya karyawan-karyawan yang bekerja secara baik ini, maka di harapkan kinerja karyawan baik juga tercapai oleh karyawan dalam melaksanakan tugasnya sesuai dengan tanggungjawab yang diberikan kepadanya.

Dalam upaya untuk mendapatkan sumber daya manusia yang berkualitas, maka pimpinan perusahaan perlu mengadakan upaya untuk menjaga, memelihara dan meningkatkan kualitas dan kuantitas kinerja dan loyalitas karyawan bagi perusahaan. Manajemen perusahaan perlu mempelajari, mengapa ada karyawan yang malas malasan, sedangkan karyawan lain bekerja dengan tekun. Mengapa karyawan sering datang terlambat dan pulang kerja secepatnya. Dan mengapa ada karyawan yang sering tidak masuk kerja, 
tidak bisa bekerja sama serta mengambil yang bukan haknya.

Banyak cara dalam mewujudkan kinerja yang baik diantaranya dapat dicapai dengan melalui pendidikan, pelatihan, pemberian kompensasi yang layak, menciptakan lingkungan kerja yang kondusif, pemberian motivasi dan sebagainnya. Dapat dikatakan semakin baik kinerja karyawan diperusahaan tersebut maka semakin mudah perusahaan mencapai tujuannya, dan sebaliknya apabila kinerja karyawan itu rendah maka semakin sulit perusahaan dalam mencapai tujuannya. Melalui cara tersebut diharapkan karyawan akan lebih memaksimalkan tanggung jawab atas pekerjaan mereka karena para karyawan telah terbekali dan hal tersebut berkaitan dengan implementasi kerja mereka. Menurut Mangkunegara (2013:67) “kinerja pegawai adalah hasil kerja secara kualitas dan kuantitas yang dicapai oleh seorang pegawai dalam melaksanakan tugasnya sesuai dengan tanggung jawab yang diberikan kepadanya".

Begitupun dengan PT. Trimulya Interbuana Tangerang Selatan yang bergerak dibidang distributor makanan dan minuman tidak terlepas dari masalah kinerja karyawan dalam hal pencapaian output secara maksimal, walaupun setiap tahunnya mengalami kenaikan tetapi dirasa kurang optimal.

Salah satu faktor penyebab penurunan kinerja karyawan disinyalir akibat dari kompensasi yang diberikan kepada karyawan kurang memadahi. Rendahnya tingkat kinerja karyawan dalam suatu perusahaan dapat dilihat dari besaran kompensasi yang diberikan oleh perusahaan dengan besarnya tanggung jawab pekerjaan yang dilakukan selain itu tingkat motivasi kerja karyawan dalam melaksanakan pekerjaan juga dikatakan sebagai rendahnya tingkat kinerja karyawan. Salah satunya dengan meningkatkan kinerja karyawan melalui pemberian kompensasi yang sesuai dengan balas jasa kepada karyawan atas usaha yang mereka lakukan kepada perusahaan, hal ini dikarenakan setiap orang bekerja memiliki motif untuk mendapat keuntungan atau manfaat dalam bekerja. Menurut Hasibuan (2016:119) "kompensasi adalah semua pendapatan yang berbentuk uang, barang langsung atau tidak langsung yang diterima karyawan sebagai imbalan atas jasa yang diberikan kepada perusahaan". Kompensasi merupakan hal yang sensitif bila dikaitkan dengan kelayakan dalam memenuhi kebutuhan, apalagi semakin besarnya tingkat kebutuhan saat ini sehingga gaji yang diberikan masih dirasa kurang cukup. Pemberian kompensasi yang adil sangat dibutuhkan oleh setiap karyawan karena dengan adanya pembagian kompensasi secara adil karyawan merasa dihargai atas usaha yang dicurahkan untuk perusahaan. Maka tentunya kedua pihak harus saling mengerti tentang kepentingan dan kebutuhan masing-masing dalam suatu perusahaan.

Kompensasi juga merupakan penghargaan yang diberikan perusahaan kepada karyawan baik langsung maupun tidak langsung, adapun kompensasi yang diberikan PT. Trimulya Interbuana Tangerang Selatan kepada para karyawannya terbagi dua, yaitu kompensasi secara finansial dan kompensasi nonfinansial. Kompensasi finansial merupakan imbalan jasa kepada karyawan yang diterima secara langsung, rutin atau periodik karena yang bersangkutan telah berkontribusi dalam mencapain tujuan perusahaan, sedangkan kompensasi nonfinancial didefinisikan sebagai balas jasa bukan dalam bentuk uang.

Berdasarkan latar belakang yang telah dipaparkan diatas maka penulis tertarik untuk melakukan penelitian dengan judul "Pengaruh Kompensasi Terhadap Kinerja Karyawan Pada PT. Trimulya Interbuana di Tangerang Selatan".

\section{TINJAUAN PUSTAKA}

\section{Kompensasi}

Menurut Hasibuan (2016:119) "kompensasi adalah semua pendapatan yang berbentuk uang, barang langsung 
atau tidak langsung yang diterima karyawan sebagai imbalan atas jasa yang diberikan kepada perusahaan".

\section{Kinerja Karyawan}

Menurut Mangkunegara (2016:67) "kinerja pegawai adalah hasil kerja secara kualitas dan kuantitas yang dicapai oleh seorang pegawai dalam melaksanakan tugasnya sesuai dengan tanggung jawab yang diberikan kepadanya".

\section{METODE}

\section{Populasi}

Yang dijadikan sebagai populasi dalam penelitian ini adalah responden yang berjumlah 52 responden PT. Trimulya Interbuana di Tangerang Selatan

2. Sampel

Teknik pengambilan sampling dalam penelitian ini adalah sampel jenuh, dimana semua anggota populasi dijadikan sebagai sampel. Dengan demikian sampel dalam penelitian ini sampel yang digunakan berjumlah 52 responden.

3. Jenis Penelitian

Jenis penelitian yang dipakai adalah asosiatif, dimana tujuannya adalah untuk mengetahui atau mencari keterhubungan antara variabel independen terhadap variabel dependennya

\section{Metode Analisis Data}

Dalam menganalisis data digunakan uji validitas, uji reliabilitas, analisis regresi linier sederhana, analisis koefisien korelasi, analisis koefisien determinasi dan pengujian hipotesis.

\section{HASIL DAN PEMBAHASAN}

\section{Analisis Deskriptif}

Pada pengujian ini digunakan untuk mengetahui skor minimum dan maksimum skor tertinggi, ratting score dan standar deviasi dari masing-masing variabel. Adapun hasilnya sebagai berikut:

Tabel 1. Hasil Analisis Descriptive Statistics

Descriptive Statistics

\begin{tabular}{lr|r|r|r|r} 
& N & Minimum & Maximum & Mean & Std. Deviation \\
\hline Kompensasi (X) & 52 & 29 & 44 & 33.48 & 3.770 \\
\hline Kinerja Karyawan (Y) & 52 & 29 & 49 & 38.13 & 4.563 \\
\hline Valid N (listwise) & 52 & & & & \\
\hline
\end{tabular}

Kompensasi diperoleh varians minimum sebesar 29 dan varians maximum 44 dengan ratting score sebesar 3,348 dengan standar deviasi 3,770. Skor ini termasuk pada rentang sakala 3,40 4,19 dengan kriteria baik atau setuju. Kinerja karyawan diperoleh varians minimum sebesar 29 dan varians maximum 49 dengan ratting score sebesar 3,813 dengan standar deviasi 4,563. Skor ini termasuk pada rentang sakala 3,40 4,19 dengan kriteria baik atau setuju.

\section{Analisis Kuantitatif}

Pada analisis ini dimaksudkan untuk mengetahui pengaruh variabel independen terhadap variabel dependen. Adapun hasil pengujian sebagai berikut:

a. Analisis Regresi Linier Sederhana

Uji regresi ini dimaksudkan untuk mengetahui perubahan variabel dependen jika variabel independen mengalami perubahan. Adapun hasil pengujiannya sebagai berikut:

Tabel 2. Hasil Pengujian Regresi Linier Sederhana Coefficients ${ }^{a}$

Unstandardized Coefficients Standardized Coefficients

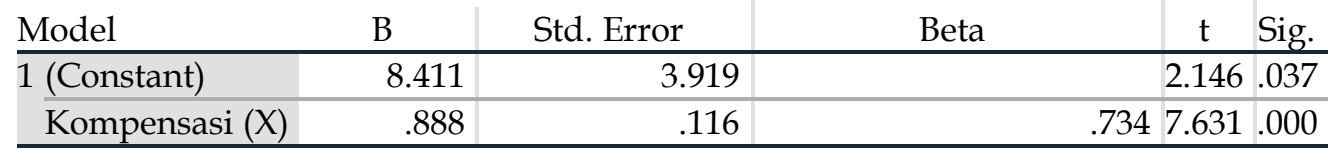

a. Dependent Variable: Kinerja Karyawan (Y) 
Berdasarkan hasil pengujian pada tabel di atas, diperoleh persamaan regresi $Y=8,411+0,888 X$. Dari persamaan tersebut dijelaskan sebagai berikut:

1) Konstanta sebesar 8,411 diartikan jika kompensasi tidak ada, maka telah terdapat nilai kinerja karyawan sebesar 8,411 point.

Koefisien regresi kompensasi sebesar 0,888, angka ini positif artinya

Tabel 3. Hasil Pengujian Koefisien Korelasi Kompensasi Terhadap Kinerja Karyawan

\section{Correlations $^{\mathrm{b}}$}

\begin{tabular}{llrrr} 
& \multicolumn{3}{c}{ Kompensasi $(\mathrm{X})$} & Kinerja Karyawan $(\mathrm{Y})$ \\
\hline Kompensasi $(\mathrm{X})$ & Pearson Correlation & 1 & $.734^{* *}$ \\
\cline { 2 - 4 } & Sig. (2-tailed) & & .000 \\
\hline Kinerja Karyawan (Y) Pearson Correlation & $.734^{* *}$ & 1 \\
\cline { 2 - 4 } & Sig. (2-tailed) & .000 & \\
\hline
\end{tabular}

**. Correlation is significant at the 0.01 level (2-tailed).

b. Listwise $\mathrm{N}=52$

Berdasarkan hasil pengujian diperoleh nilai korelasi sebesar 0,734 artinya kompensasi memiliki hubungan yang kuat terhadap kinerja karyawan.

Tabel 4. Hasil Pengujian Koefisien Determinasi Kompensasi Terhadap Kinerja Karyawan.

\section{Model Summary}

Model R R Square Adjusted R Square Std. Error of the Estimate

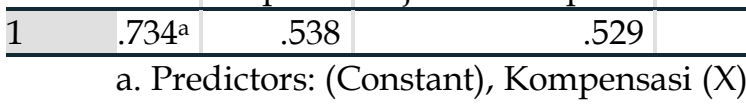

Berdasarkan hasil pengujian diperoleh nilai determinasi sebesar 0,538 artinya kompensasi memiliki kontribusi pengaruh sebesar 53,8\% terhadap kinerja karyawan, sedangkan sisanya sebesar $46,2 \%$ dipengaruhi oleh faktor lain yang tidak dilakukan penelitian.

Tabel 5. Hasil Uji Hipotesis Kompensasi Terhadap Kinerja Karyawan.

\section{Coefficients ${ }^{\mathrm{a}}$}

Unstandardized Coefficients Standardized Coefficients

\begin{tabular}{lr|rrrrr} 
Model & B & Std. Error & Beta & $t \quad$ Sig. \\
\hline 1 (Constant) & 8.411 & 3.919 & & 2.146 .037 \\
\hline Kompensasi (X) & .888 & .116 & & .7347 .631 .000 \\
\hline
\end{tabular}

a. Dependent Variable: Kinerja Karyawan $(\mathrm{Y})$

Berdasarkan hasil pengujian pada tabel di atas, diperoleh nilai $t$

\section{d. Uji Hipotesis}

Pengujian hipotesis dengan uji $\mathrm{t}$ digunakan untuk mengetahui hipotesis mana yang diterima.

Rumusan hipotesis: Terdapat pengaruh yang signifikan kompensasi terhadap kinerja karyawan.

\footnotetext{
pada tabel di atas, diperoleh nilait
} 
diajukan bahwa terdapat pengaruh yang signifikan atara kompensasi terhadap kinerja karyawan diterima

\section{PEMBAHASAN HASIL PENELITIAN}

\section{Kondisi Jawaban Responden Variabel Kompensasi}

Berdasarkan jawaban responden, variabel kompensasi diperoleh ratting score sebesar 3,348 berada di rentang skala 3,40 - 4,19 dengan kriteria baik atau setuju.

\section{Kondisi Jawaban Responden Variabel Kinerja Karyawan}

Berdasarkan jawaban responden, variabel kinerja karyawan diperoleh ratting score sebesar 3,813 berada di rentang skala 3,40 - 4,19 dengan kriteria baik atau setuju.

\section{Pengaruh Kompensasi Terhadap Kinerja Karyawan \\ Kompensasi \\ berpengaruh}

signifikan terhadap kinerja karyawan dengan persamaan regresi $\mathrm{Y}=8,411+$ $0,888 \mathrm{X}$, nilai korelasi sebesar 0,734 atau memiliki hubungan yang kuat dengan kontribusi pengaruh sebesar 53,8\%. Pengujian hipotesis diperoleh nilai $t$ hitung $>\mathrm{t}$ tabel atau $(7,631>2,009)$. Dengan demikian hipotesis yang diajukan bahwa terdapat berpengaruh signifikan antara kompensasi terhadap kinerja karyawan diterima.

\section{PENUTUP}

\section{Kesimpulan}

a. Variabel kompensasi diperoleh ratting score sebesar 3,348 berada di rentang skala 3,40 - 4,19 dengan kriteria baik atau setuju.

b. Variabel kinerja karyawan diperoleh ratting score sebesar 3,813 berada di rentang skala 3,40 - 4,19 dengan kriteria baik atau setuju.

c. Kompensasi berpengaruh signifikan terhadap kinerja karyawan dengan persamaan regresi $Y=8,411+0,888 X$, nilai korelasi sebesar 0,734 atau kuat dan kontribusi pengaruh sebesar
$53,8 \%$ sedangkan sisanya sebesar $46,2 \%$ dipengaruhi faktor lain. Uji hipotesis diperoleh nilai $\mathrm{t}$ hitung $>\mathrm{t}$ tabel atau $(7,631>2,009)$.

\section{Saran}

a. Meskipun mendapatkan jaminan atas Kesehatan dan keselamatan kerja namun hal tersebut belum sesuai dengan resiko pekerjaan, maka sebaiknya jaminan Kesehatan dan keselamatan kerja disesuaikan dengan resiko kerja karyawan.

b. Karyawan melakukan pekerjaan kurang sesuai dengan target yang telah ditetapkan. Hal ini menandakan bahwa karyawan masih belum mampu menyelesaikan tugas secara efektif dan efesien, maka seharusnya perusahaan meningkatkan kinerja karyawan melalui motivasi dan kompensasi yang sesuai dengan tugas dan pekerjaan karyawan.

\section{DAFTAR PUSTAKA}

Abdullah. M (2014). Manajemen dan Evaluasi Kinerja Karyawan. Yogyakarta: Penerbit Aswaja Pressindo.

Algifari. (2015). Analisis Regresi untuk Bisnis dan Ekonomi. Yogyakarta: BPFE.

Arikunto, Suharsimi (2014). Prosedur Penelitian Suatu Pendekatan Praktek. Tangerang Selatan: Rineka Cipta.

Bangun, Wilson. (2012). Manajemen Sumber Daya Manusia. Tangerang Selatan: Erlangga

Bejo Siswanto (2013) Manajemen Tenaga Kerja Rancangan dalam Pendayagunaan dan Pengembangan Unsur Tenaga Kerja. Bandung: Sinar Baru.

Dessler, G. (2006.). Manajemen Sumber Daya Manusia. Jilid II. Tangerang Selatan: Indeks.

Edi Sutrisno (2016). Manajemen Sumber Daya Manusia. Tangerang Selatan: Prenadamedia Group.

Edi Sutrisno (2016). Manajemen Sumber Daya Manusia. Tangerang Selatan: Prenadamedia Group.

George Terry R \& Rue, Leslie W. Rue (2016). Dasar-Dasar Manajemen. Tangerang 
Selatan Bumi Aksara.

Gerry Dessler (2016). Human Resources Management. Prenticehall. London: International Inc.

Handoko (2016). Manajemen Personalia dan Sumberdaya Manusia. Yogyakarta: BPFE.

Hasibuan, Malayu S.P. (2016). Manajemen Sumber Daya Manusia. Edisi Revisi. Tangerang Selatan: PT Bumi Aksara.

Imam Ghozali (2017). "Aplikasi Analisis Multivariate Dengan Program SPSS". Edisi Kelima. Semarang: Badan Penerbit Undip.

Istijanto (2014) "Riset Sumber Daya Manusia". Tangerang Selatan: PT. Gramedia Pustaka

Kosasih, K., et al. (2020). The Effect of Compensation and Service Period on Employee Performance at PT. Infomedia Nusantara Branch
Bandung. Kontigensi: Jurnal Ilmiah Manajemen, 8(2), 147-154.

Luthans Fred (2014). Organizational Behavior. Ney York: McGraw-Hill. New York.

Mangkunegara, Prabu Anwar. (2016). Evaluasi Kinerja SDM. Cetakan ke tujuh, PT Refika Aditama: Bandung.

Robbins, P.S, \& Judge, A.T. (2003). Organizational Behavior. Tangerang Selatan: Salemba Empat.

Sedarmayanti, A. et al(2021). The Role Of Knowledge Management And Innovation Management On Manufacturing Performance. Turkish Journal of Physiotherapy and Rehabilitation, 32, 3.

Seta, A. B., et al. (2021). Pengaruh Pelatihan Dan Kompensasi Terhadap Prestasi Kerja Yang Berdampak Pada Kinerja Karyawan Pada PT Cipta Mega Sarana Di Jakarta. Jurnal Ekonomi Efektif, 4(1), 148-159. 